\title{
KRITIČKI OSVRT NA POIMANJE APOSTOLATA U DJELIMA ŽIVANA BEZIĆA
}

\author{
Ivica Jurić
}

Katolički bogoslovni fakultet

UDK: Bezić, Ž.2-05:272-774-46

Sveučilišta u Splitu 272-722.7

ivicajurich@gmail.com

Pregledni znanstveni rad

Primljeno 02/2019

\section{Sažetak}

U radu autor promišlja o apostolatu na temelju pisanih knjiga $i$ članaka Živana Bezića, jednog od najplodnijih pastoralnih teologa $u$ Hrvatskoj u drugoj polovici prošlog stoljeća. U prvom dijelu rada iznosi Bezićevo teološko-pastoralno promišljanje o značenju, povijesnoj upotrebi i temeljima apostolata. U drugom dijelu rada govori o Bezićevoj podjeli, sursi i područjima apostolata. U trećem dijelu autor se u svjetlu suvremenih dostignuća pastoralne teologije, sa stajališta lateranske škole, kritički osurće na Bezićevo teološko-pastoralno promišljanje apostolata, na njegovu podjelu te područja i subjekte apostolata. Pastoralni teolog Bezić apostolat promišlja u tradicionalnom duhu $i$ sam pojam apostolata ne upotrebljava jednoznačno u svojim djelima.

Ključne riječi: Živan Bezić, apostolat, pastoral, pastoralka, pastorizacija, vjernici laici

\section{UVOD}

I sasvim kratak pogled na životopis i bibliografiju don Živana Bezića, svećenika Splitsko-makarske nadbiskupije i profesora pastoralne teologije (1921. - 2007.), otkriva da se radi o značajnom pastoralnom teologu koji je svojim teološkim opusom obilježio postkoncilsko razdoblje u našoj Crkvi. Uzevši u obzir činjenicu da se Bezić osim profesorskim zvanjem, dakle predavanjem i pisanjem teoloških radova iz različitih teoloških i neteoloških grana znanosti, dugi niz godina bavio i pastoralom u praksi, kao zauzeti župnik, čovjek ne može a da ne ostane zadivljen kako kvantitetom tako i raznolikošću tema i područja kojima se tijekom svojega plodnog znanstvenoteološkog rada bavio. Naime, Bezićev se znanstveni opus proteže na različita znanstvena područja, počevši od teološkoga, preko pedagoš- 
kog, psihološkog, sociološkog pa sve do književnog područja. ${ }^{1}$ Sve navedeno nesumnjivo otkriva da se radi o čovjeku goleme erudicije i životnog iskustva, svestranom i zauzetom pastoralnom teologu koji je u djelo provodio ono što je generacijama mladih kandidata za svećeništvo na predavanjima izlagao. Kao pastoralnog teologa na osobit me način zanima njegov, mogu to unaprijed reći, nedovoljno istražen, a onda posljedično i nedovoljno valoriziran doprinos razvoju i znanstvenom pozicioniranju pastoralne teologije na hrvatskom govornom području. O nesumnjivim zaslugama za navedeno svjedoče i riječi fra Bonaventure Dude, našeg poznatog bibličara, koji je $u$ prigodi svečane dodjele počasnog doktorata teologu Beziću od strane Katoličkoga bogoslovnog fakulteta u Zagrebu 1990. godine istaknuo kako mu tu čast odaju zbog „,velike zasluge u njegovanju i promicanju teoloških znanosti [...] osobito na području pastoralnog i duhovnog bogoslovlja“. ${ }^{2}$ Kako bi spomenutu 'nepravdu' barem donekle ispravio, Katolički bogoslovni fakultet u Splitu, na kojem je Bezić dugo godina predavao, ${ }^{3}$ organizirao je prije dvije godine, a u prigodi desete obljetnice njegove smrti, znanstveni skup o njegovu životu i djelu te izdao i zbornik njemu u čast. ${ }^{4}$ Nadam se da će i ovaj skromni doprinos o Bezićevu poimanju apostolata tu 'nepravdu' još dodatno umanjiti. U prvom poglavlju govorit ćemo o tome što Bezić podrazumijeva kad govori o apostolatu, kako ga pokušava definirati i koji su mu nositelji. U drugom bit će govora o vrstama i područjima pastorala kako ih Bezić u svojim djelima izlaže. U trećem poglavlju kritički ćemo se osvrnuti na Bezićevo promišljanje pastorala i pastoralne teologije $\mathrm{u}$ okviru zadane teme. U odgovoru na gore navedena pitanja oslanjamo se poglavito na sljedeća autorova djela: Pastoral-

$1 \quad$ Za detaljniji uvid u opus don Živana Bezića vidjeti njegovu bibliografiju, koja broji 321 naslov, a koju je Jure Strujić prikupio i donio u zborniku priređenu Živanu Beziću u čast, u prigodi desete obljetnice njegove smrti. Usp. Jure Strujić, Bibliografija don Živana Bezića, u: Alojzije Čondić i Mladen Parlov (ur.), Živan Bezić, teologija i pastoral, Zbornik radova znanstvenog skupa o životu i djelu don Živana Bezića, povodom desete obljetnice njegove smrti, Split, 22. XI. 2017., CUS, 2017., 197-225 (dalje: Živan Bezić, teologija i pastoral).

2 Slavko Kovačić, Bilješka o znanstvenom radu prof. don Živana Bezića, u povodu dobivanja naslova doctor honoris causa, u: Vjesnik nadbiskupije splitsko-makarske 5/6 (1989.), 28-29.

3 Živan Bezić kao profesor pastoralne teologije predavao je u Splitu na tadašnjoj Visokoj bogoslovnoj školi od 1967. godine do svoga umirovljenja 1995. Usp. Slavko Kovačić, Životni put don Živana Bezića, u: Živan Bezić, teologija i pastoral, 18. (dalje: Životni put don Živana Bezića).

$4 \quad$ Usp. Živan Bezić, teologija i pastoral, 1-239. 
ni radnik, ${ }^{5}$ Pastoralni rad $^{6}$ i Pastoralnu službu, ${ }^{7}$ dakle na pastoralnu trilogiju u kojoj Bezić donosi panoramu katoličke pastoralke. Osim navedenih priručnika, po kojima je teolog Bezić i najprepoznatljiviji, jer predstavljaju raritetni primjerak cjelovite pastoralke na našem prostoru, koristili smo se i njegovom knjigom Tko je apostol?, i to novijim, dopunjenim izdanjem iz $1996 .^{8}$ godine, kao i knjigom Suvremena župa, iz 1987. godine. ${ }^{9}$

\section{Apostolat prema Beziću}

Odmah na početku treba istaknuti kako nije nimalo jednostavan zadatak jednoznačno iznijeti ono što je Bezić smatrao i u svojim teološkim radovima nazivao apostolatom. Naime, definicije apostolata kojima se koristio u svojim djelima nisu ujednačene. Donosimo samo nekoliko primjera koji će navedeno potvrditi. Na početku trećeg sveska pastoralne trilogije, u okviru govora o diakoniji, a sažimajući pritom prethodna dva sveska, Bezić ističe: "Kako smo već proučili službu Bogu (evangelizacija, moralka, asketika, liturgija), preostaje nam da razmotrimo službu čovjeku u njegovim tjelesnim (karitas) i duševnim potrebama (apostolat)."10 Nekoliko stranica dalje, $\mathrm{u}$ istome svesku, autor navedenu misao još jasnije izražava ustvrdivši: „Pored služenja čovjeku u njegovim tjelesnim nevoljama

$5 \quad$ Usp. Živan Bezić, Pastoralni radnik, II. prerađeno izdanje, HKD Sv. Ćirila i Metoda, Zagreb, 1982., 1-253 (dalje: Pastoralni radnik).

6 Usp. Živan Bezić, Pastoralni rad, (Katolička pastoralka), II. prerađeno izdanje, HKD Sv. Ćirila i Metoda, Zagreb, 1983., 1-338. (dalje: Pastoralni rad).

7 Usp. Živan Bezić, Pastoralna služba, (Katolička pastoralka), II. prerađeno izdanje, HKD Sv. Ćirila i Metoda, Zagreb, 1985., 1-244 (dalje: Pastoralna služba); Navedenu trilogiju svojih priručnika za pastoralnu teologiju Bezić je najprije izdao ciklostilom za potrebe studenata teologije u Splitu u nakladi Centralne Visoke bogoslovske škole: Pastoralni radnik (Katolička pastoralka), Centralna Visoka bogoslovska škola, Split, 1969.; Pastoralni rad (Katolička pastoralka), sv. II., Centralna Visoka bogoslovska škola, Split, 1970., Pastoralna služba (Katolička pastoralka), sv. III., Centralna Visoka bogoslovska škola, Split, 1971. Nakon desetak godina ponovno je objavio sva tri sveska u izdanju HKD-a sv. Ćirila i Metoda iz Zagreba sa značajnim dopunama. Osobito se to odnosi na treći svezak (Pastoralna služba), $\mathrm{u}$ dijelu u kojem obrađuje pastoral sakramenata, a koji je uskladio s novim Zakonikom kanonskog prava. Usp. Ivan Šarčević, Pastoralna teologija od Andrića do Bezića, Prikaz hrvatskih udžbenika pastoralne teologije 19. i 20. stoljeća, u: Stipe Nimac, Praktična teologija danas, stanje i perspektive, Ravnokotarski cvit, Lepuri, 2017., 214. (dalje: Pastoralna teologija od Andrića do Bezića).

$8 \quad$ Usp. Živan Bezić, Tko je apostol?, Crkva u svijetu, Split, 1996., 1-238 (dalje: Tko je apostol?).

9 Usp. Živan Bezić, Suvremena župa, Služba Božja, Makarska, 1987., 1-192 (dalje: Suvremena župa).

10 Pastoralna služba, 13. 
potrebna je i služba njegovoj duši, što zovemo općim imenom apostolat [...]",te nastavlja referirajući se na isto, pritom naglašavajući kako je apostolat „bitna komponenta kršćanskog, a osobito svećeničkog poslanja“. ${ }^{11}$

U drugom, novijem tekstu, u knjizi Tkoje apostol? iz 1996. godine definiciju apostolata, koja se u prethodnom tekstu odnosila na službu potrebama duše, na osobit način na službu od strane svećenika, Bezić znatno proširuje, ističući kako apostolat u kršćanskom smislu znači „poslanje od Boga, izabranje i poslanje od Krista, svjedočanstvo Isusova života, smrti, i uskrsnuća, djelo i rad apostola, služba u Crkvi, apostolsko nasljedstvo, širenje dobre Vijesti i evangelizacija svijeta“. ${ }^{12} \mathrm{Na}$ drugom pak mjestu, u sažetijem obliku u odnosu na prethodne, navodi kako smijemo kršćanski apostolat definirati kao „naše sudjelovanje u poslanju Kristovu“. ${ }^{13}$ Čini se da je i sam Bezić svjestan činjenice kako pojam apostolat rabi u višestrukom značenju. To zaključujemo jer smatramo da bi to mogao biti razlog zbog kojeg upotrebu navedenog pojma detaljno tumači u etimološkom, povijesnom i suvremenom smislu. Prva dva aspekta obrađuje u knjizi/priručniku Pastoralna služba, a treći u knjizi Tko je apostol?.

\subsection{Apostolat $\mathrm{u}$ etimološkom i povijesnom smislu}

S etimolološkog aspekta pojam apostolat potječe od grčkoga glagola apostellein, koji u latinskom jeziku odgovara glagolu mitte$r e$, a u talijanskom mandare, a znači slati, poslati. ${ }^{14}$ Odatle i imenica apóstolos u značenju poslanik, predstavnik, vjesnik. Važno je ovdje istaknuti kako navedeni pojam kod Bezića istodobno označuje i osobu i službu poslanika. Drugim riječima, označuje, dakle, samog poslanika, predstavnika, i poslanje, misiju. ${ }^{15}$

U povijesnom smislu pojam apostolat ponajprije se odnosi na misiju i službu dvanaestorice Isusovih učenika, kojima je poslije dodijeljen i Pavao, ističe Bezić. Evanđelje i tradicija Crkve naziva ih apostolima. Naravno, prvi apostol ili praapostol je sam Krist, u punom smislu riječi, jer je on jedini posrednik između Boga i ljudi (usp. 1 Tim 2,5). U širem značenju apostolat se, prema Beziću, odnosi na pastoralni rad cijele Crkve. On zapravo predstavlja nastavak

\footnotetext{
11 Isto, 20.

12 Usp. Tko je apostol?, 8.

13 Tko je apostol?, 15.

14 Usp. E. Nunnenmacher, Evangelizzazione, u: Dizionario di missiologia, Pontificia Università Urbaniana, EDB, Bologna, 1993., 245.

15 Usp. Tko je apostol?, 7-8.
} 
rada izabrane dvanaestorice. U užem, pak, značenju on je izravno svjedočanstvo pojedinih katolika za Krista, na poseban način vjernika laika u odnosu prema inovjercima i nekatolicima. Konačno, u najužem značenju, apostolat, prema Beziću, označuje crkveni rad na jednom specijaliziranom području katoličkog svjedočanstva, kao što je primjerice apostolat molitve, apostolat zvanja, apostolat bolesnika i sl. ${ }^{16}$

\subsection{Apostolat u suvremenom smislu}

Nakon etimološkoga i povijesnog aspekta te uporabe pojma u širem, užem i najužem smislu autor o suvremenom aspektu, odnosno današnjem značenju i upotrebi pojma apostolat govori u knjizi Tkoje apostol?. Premda na samom početku, u predgovoru, napominje kako "ono što se u nekim teološkim učilištima za laike uči pod naslovom 'pastoral' mi to ovdje obrađujemo pod nazivom apostolat", ${ }^{17}$ ipak se u navedenoj knjizi toga ne drži. Naime, kod Bezića se apostolat u novijim djelima odnosi na laički apostolat, a svećenički apostolat on naziva pastoralom. ${ }^{18} \mathrm{U}$ tom smislu, o upadnoj usmjerenosti pastoralne teologije, ili pastoralke, kako je naš teolog naziva, na župničku pastoralnu službu svjedoči njegova sljedeća misao: „Pastoralna služba svećenikova tako je važna da je po njoj nazvana i čitava nauka o svećeničkoj službi." 19 U knjizi, pak, Suvremena župa, koju je objavio gotovo deset godina prije knjige Tkoje apostol, navedenu podjelu djelomično potvrđuje ističući ipak kako je apostolat zajedničko djelo svih pripadnika crkvene zajednice. U navedenom djelu Bezić piše: „Uz pastoral, koji je uglavnom djelo pastira, na općem vjerskom dobru moraju sudjelovati svi kršćani, bez iznimke i bez rezerve. To je zajedničko poslanje - apostolat - svih pripadnika osnovne crkvene zajednice. On je jednako laički kao i klerički, zajedničko djelo čitave župe."20 Ili, na drugome mjestu, u istoj knjizi, govoreći o otkupiteljskom poslanju svih kršćana preko tri glavne službe (evangelizacija, bogoslužje, bratoslužje - dijakonija), ističe: „Kada te službe vrše svećenici, onda ih obično sve skupa stavljamo pod pojam pastorala. Ukoliko ih obavljaju svećenici i laici skupa, ili pak samo laici, obično se zovu vršenje crkvenog poslanja ili

16 Usp. Pastoralna služba, 20-21.

17 Tko je apostol?, 5.

18 Usp. Tko je apostol?, 58; usp. Alojzije Čondić, Glavni vidovi pastoralne teologije i pastorala Živana Bezića, u: Živan Bezić, teologija i pastoral, 36.

19 Pastoralna služba, 7; usp. Pastoralni radnik, 14.

20 Suvremena župa, 29. 
jednostavno apostolat. “21 Navedena tvrdnja ipak ga ne priječi da $u$ kasnijim djelima, tj. u novijem izdanju svoje poznate knjige koju je posvetio apostolatu laika, navedenu usmjerenost u pastoralu na rad župnika u župnoj zajednici, a koja je posljedica promišljanja pastorala u tradicionalnom duhu, ističe još izričitije: „Kad se danas govori o svećeničkom radu, radije se upotrebljava riječ pastoral [...] a kad se u naše doba upotrebljava riječ 'apostolat' jednostavno, bez ikakva atributa i ograničenja, onda se redovito misli na laički apostolat [...] te nastavlja - spremno prihvaćajući tu činjenicu, i mi ćemo se služiti tim nazivom, podrazumijevajući pod tim apostolat katoličkih laika.“22

Sintetizirajući dosad izloženo, ističemo kako smo kod Bezića od apostolata definiranog u početku vrlo restriktivno, kao službu čovjeku u duševnim potrebama, i to kao bitnu komponentu osobito svećeničkog poslanja, došli najprije do njegove vrlo široke definicije koja kao subjekte uključuje sve članove župne zajednice i mnoštvo međusobno različitih aktivnosti u vršenju poslanja Crkve, a zatim i do toga da se apostolat u suvremenom teološkom diskursu odnosi isključivo na apostolat vjernika laika, a pastoral, odnosno pastoralizacija, kako je Bezić nazivao pastoral, na svećenike. Ovakva podjela, koja stvara konfuziju, osobito ako ju se gleda iz perspektive današnjih promišljanja pastoralne teologije o crkvenom poslanju, odraz je tradicionalne impostacije pastorala i pastoralke, po kojoj nositelj pastoralnih aktivnosti u župnoj zajednici nije sama zajednica (na temelju krštenja i sinodalne svijesti), nego sam pastir. Premda Bezić rado, na tragu saborske ekleziologije zajedništva, govori o Crkvi kao narodu Božjem, ${ }^{23}$ naglašavajući ulogu i značenje vjernika laika u poslanju Crkve, ${ }^{24}$ ipak pripada zagovornicima tradicionalne postavke pastoralnog djelovanja jer ističe kako je „materijalni objekt pastoralke djelovanje crkvenih pastira“ 25 ili kako je „dužnost pastoralke da vječne principe crkvenog djelovanja primijeni na suvremene uvjete života“. ${ }^{26}$

\subsection{Izvor, svrha i subjekti apostolata}

Nakon što smo pojasnili značenje, povijesnu uporabu i neujednačenosti glede uporabe pojma apostolat, možemo prijeći na novu temu

\footnotetext{
21 Isto, 141.

22 Tko je apostol?, 12-13; usp. Isti, 58; usp. Pastoralni radnik, 12-13.

23 Usp. Pastoralni radnik, 34-35.

24 Usp. Pastoralni radnik, 142-150, 160-164; usp. Suvremena župa, 113-116, 124-126.

25 Pastoralni radnik, 12.

26 Isto, 10.
} 
- izvor, svrhu i subjekte apostolata prema Beziću. Izvor apostolata je u Presvetom Trojstvu: Bog Otac šalje svoga Sina na zemlju da otkupi ljudski rod, a Otac i Sin šalju Duha Svetoga da ga posveti. Stoga prvi apostolat, prema Beziću, predstavlja poslanje druge i treće božanske osobe. Krist koji je prvi i pravi Božji apostol, odnosno praapostol, jedini posrednik između Boga i ljudi (usp. 1 Tim 2,5), svoje božansko poslanje prenio je na Crkvu. U Crkvi su prvi apostoli bili dvanaestorica od Isusa izabranih, zatim njihovi nasljednici biskupi na čelu $\mathrm{s}$ Petrovim nasljednikom. S vremenom se pojam apostolata prenio i na svećeničku i redovničku službu, a u najnovije se vrijeme, kako smo prethodno vidjeli, prema Beziću, odnosio samo na laički apostolat. ${ }^{27}$

Koja je, prema Beziću, svrha apostolata? Na postavljeno pitanje Bezić odgovara kako je to slava Božja i dobro bližnjega. Dobro bližnjega u tom smislu znači spasenje i posvećenje bližnjega, odnosno cijeloga društva. ${ }^{28}$ Nadalje, možemo se pitati i tko je apostol, odnosno tko su nositelji, subjekti apostolata prema Beziću. Inače, prije odgovora na navedeno pitanje, a kurioziteta radi, istaknimo kako i jedna Bezićeva knjiga u samom naslovu sadrži navedeno pitanje. Dakle, nakon povijesnog presjeka u kojem sabire sazrijevanje kršćanske misli razlažući na koga se sve tijekom povijesti kršćanstva odnosio naziv apostol i apostolat, teolog Bezić zaključuje kako su svi kršćani apostoli, neovisno o tomu jesu li posvećeni sakramentom svećeništva, ili redovničkim zavjetima, ili se pak radi o vjernicima laicima. Njihova dužnost i zajedničko poslanje jest izgrađivati kraljevstvo Božje, a to će moći, ističe, ako prethodno budu dobro odgojeni, tj. ako razviju svijest o dužnosti sudjelovanja sviju u crkvenom poslanju. ${ }^{29}$

Navedena dužnost sudjelovanja, odnosno suodgovornosti za poslanje proizlazi iz sakramenta krštenja, iz krsnog biljega koji u krštenju primaju svi, neovisno o statusu i službama, društvenim ili crkvenim. Svi su vjernici apostoli, imaju zajedničko poslanje, koje, doduše, vrše na različite načine sukladno službama, zaduženjima, karizmama i kompetencijama svakog pojedinog. O toj temi bit će još govora u nastavku, budući da su kod Bezića, kako smo se i prethodno osvjedočili govoreći o pastoralu i apostolatu, prisutne nemale neujednačenosti kad je riječ o subjektima pastoralnog djelovanja. Ukratko, premda Bezić rado ističe da je pastoral zajednički rad svećenika i vjernika te da laici nisu samo objekti već i subjekti u pastoralu, on ga ipak (rabeći pritom često pojam pastorazacije umjesto pastorala) uglavnom pripisuje svećenicima te tako ostaje zatoče-

27 Usp. Tko je apostol?, 11-13; Pastoralni radnik, 12-13.

28 Usp. Tko je apostol?, 23.

29 Usp. Pastoralni radnik, 10-11, Tko je apostol?, 23. 
nikom tradicionalnoga tridentskog modela impostacije pastorala, koji je još, nažalost, utisnut u mentalitet nemalog broja pastoralnih suradnika, bilo svećenika bilo vjernika laika.

\section{VRSTE I PODRUČJA APOSTOLATA}

\subsection{Opći (hijerarhijski i laički) apostolat}

Živan Bezić apostolat dijeli na opći, direktni i specijalizirani. Na prvome mjestu ističe opći apostolat, u kojem su na temelju krštenja i drugih sakramenata dužni sudjelovati svi vjernici. Premda su za apostolat suodgovorni svi, oni to ipak nisu na jednak način. Naime, opseg sudjelovanja u apostolatu ovisi o pozivu, službi, sposobnosti i mogućnostima svakog pojedinog vjernika. Opći apostolat Bezić dijeli na laički i hijerarhijski apostolat. ${ }^{30}$ Referirajući se na dogmatsku konstituciju Lumen gentium br. $31,{ }^{31}$ ističe kako je apostolat u svijetu specifično područje laičke djelatnosti. Premda tvrdi kako svećenik ima službu ponajprije u Crkvi, a laik u svijetu, ipak upozorava kako se navedena tvrdnja nipošto ne smije shvatiti jednostrano i u isključivu obliku ${ }^{32}$.

Tu konstataciju dodatno pojašnjava riječima: „Ako je rad u svijetu glavna dužnost i pravo katoličkog laika, time nismo rekli da za nj nema posla i u njegovoj Crkvi. [...] Kao što je dužnost svećenika da bude direktno i primarno angažiran unutar Crkve, a u svijetu samo indirektno, tako je dužnost laika da - ako je već izravno angažiran u svijetu - u svojoj Crkvi bude angažiran barem indirektno, ali sa svim srcem. " ${ }^{33} \mathrm{O}$ tome što vjernik laik može i treba raditi na specifično crkvenom području, autor govori dosta opširno, a mi za

30 Usp. Pastoralna služba, 23.

31 „Laicima je svjetovna narav vlastita i posebna. [...] Na laike spada po njihovu pozivu da traže kraljevstvo Božje baveći se vremenitim stvarima i uređujući ih po Bogu. Žive u svijetu, to jest u svim i pojedinim dužnostima i poslovima svijeta i u redovitim prilikama obiteljskog i društvenog života, kojima je kao protkan njihov život. Tu su oni od Boga pozvani, da pridonesu; kao iznutra poput kvasca, posvećenju svijeta vršeći vlastitu dužnost, vođeni evanđeoskim, duhom, i tako drugima otkriju Krista u prvom redu svijetleći svjedočanstvom svoga života, vjerom, nadom i ljubavlju. Na njih dakle posebnim načinom spada da sve vremenite stvari, s kojima su tijesno vezani, tako rasvijetle i urede da se uvijek vrše po Kristu i da rastu i budu na slavu Stvoritelja, i Otkupitelja." Drugi Vatikanski koncil, Dogmatska konstitucija o Crkvi - Lumen gentium, KS, Zagreb, 1986., br. 31 (dalje: Gaudium et spes).

32 Usp. Pastoralna služba, 23-26.

33 Pastoralna služba, 25. 
ovu prigodu izdvajamo samo nekoliko primjera: aktivno sudjelovati u pripremanju i slavlju bogoslužja, katehezirati različite skupine vjernika, evangelizirati u svom domu, susjedstvu, na radnome mjestu, kulturno, socijalno i karitativno djelovati, ministrirati, pjevati u zboru, biti sakristani, biti izvanredni djelitelj pričesti, biti članovi pastoralnog vijeća itd. ${ }^{34}$

Hijerarhijski apostolat, koji Bezić još naziva i službeni apostolat, vrše samo neki vjernici, i to službeno u ime Crkve. Izvori hijerarhijskog apostolata mogu biti sv. red, jurisdikcija, missio canonica i crkveni mandat. Hijerarhijski apostolat, nadalje, autor dijeli na dva područja: svećenički (glavni) apostolat, koji naziva pastoralom, i pomoćni apostolat, koji vrše redovnici i vjernici laici. ${ }^{35}$ To nisu bilo koji vjernici laici, nego, ističe autor, samo oni koji imaju kanonsku misiju, npr. da dobiju na upravu jednu župu, ili da im je povjeren vjerski odgoj, docentura, podjela nekih sakramenata, ili da imaju mandat od Crkve kao primjerice članovi Katoličke akcije, ili da su članovi pastoralnih vijeća. ${ }^{36}$ Nadalje, laički apostolat u smislu provedbe dijeli na individualni, organizirani i službeni. Službeni ovdje znači povjeren u ime Crkve preko spomenutih načina: kanonske misije, mandata i sudjelovanja u pastoralnim vijećima.

Naravno da nam ovaj ekleziološki deficit, diskurs o glavnom, svećeničkom, i pomoćnom, odnosno nesamostalnom apostolatu redovnika ${ }^{37}$ i vjernika laika, odmah upada u oči, štoviše, iritira nas,

34 Usp. Pastoralni radnik, 226-227; Pastoralna služba, 25-26; usp. Suvremena župa, 142-144.

35 „Kako se uobičajilo da se svećenički apostolat zove općenito pastoralom (zbog njihove pastirske službe), to se termin apostolat danas upotrebljava uglavnom za redovničko i laičko crkveno djelovanje. Pogotovo je taj naziv na mjestu onda kada laici i službeno sudjeluju u hijerarhijskom apostolatu svećenika. Ta njihova suradnja s pastirima Crkve zove se pomoćni apostolat. Njega mogu vršiti samo oni laici koji su za to izričito pozvani od Crkve." Pastoralna služba, 27. Ovdje također možemo i moramo donijeti i suprotnu autorovu tvrdnju, koja otežava zauzimanje jasnog stava o tome koji su „pravi“ nositelji, subjekti u pastoralnom djelovanju Crkve. Naime, Bezić na drugome mjestu sasvim jasno odbacuje pretkoncilsku klerocentričnost u pastoralu i pišući o mjestu i ulozi vjernika laika u poslanju Crkvu u duhu ekleziologije zajedništva samokritički ističe: „Mi svećenici ne smijemo shvaćati laički apostolat samo kao nadopunu našeg svećeničkog. Uloga je laika po sebi važna, potrebna i nenadomjestiva. Bez nje Crkva ne može postojati, ona je bitni dio crkvenog pastorala. Ako bismo mi evangelizaciju svijeta htjeli svojatati samo sebi kao svećenicima te pokušali isključiti ostale vjernike iz apostolskog rada, učinili bismo tešku - pače fatalnu - pastoralnu pogrešku.“ Pastoralni radnik, 163-164.

36 Usp. Isto, 26-27.

37 Na pitanje jesu li redovnici također dužni sudjelovati u pastoralnom radu Crkve, Bezić odgovara: „Najprije moramo reći: oni, ukoliko su redovnici, a pogotovo 
budući da dijelimo drukčiju, moderniju viziju Crkve i impostaciju pastorala u kojoj nema više govora o glavnom i pomoćnom i u kojem je cijela župna zajednica subjekt pastoralnih aktivnosti. ${ }^{38}$ Drugo što valja naglasiti jest da dodjela pastoralnih službi vjernicima laicima, dakle, priznanje njihove subjektivnosti u pastoralnom djelovanju nije nešto dopunsko, fakultativno, već konstitutivno. ${ }^{39}$ To da je cijela župna zajednica subjekt pastoralnih aktivnosti, ne znači da svi u župnoj zajednici rade sve ili su zaduženi za sve, već da poslanje vrše sukladno službama, zaduženjima, karizmama i kompetencijama svakoga pojedinog vjernika. U vršenju zajedničke misije/poslanja važno je djelovati u duhu sinodalnosti: zajednički vršiti primljeno poslanje uvažavajući raznolikost drugih i doprinos svakog pojedinog člana. Drugim riječima, to znači komplementarno djelovati kroz dijalog i suradnju, čineći da sinergija različitih pastoralnih subjekata plodno impregnira društveno tkivo kršćanskim vrijednostima.

\subsection{Direktni i specijalizirani apostolat}

Kako smo prije spomenuli, osim općeg apostolata koji autor dijeli na hijerarhijski i laički postoji još i direktni i specijalizirani apostolat. Direktni ili, kako ga još teolog Bezić naziva, angažirani apostolat može se odvijati izvan i unutar Crkve. Ako se odvija izvan okvira Crkve, onda može biti ekumenski, ako se vrši među odijeljenim kršćanima, ili pak misijski, ako se vrši među nekršćanima. Ako se vrši unutar Crkve, među, kako ih Bezić naziva, „lošim“ katolicima, koji, premda nisu načelno ni pravno, de iure, prekinuli vezu $\mathrm{s}$ Crkvom, ipak su je prekinuli stvarno, de facto, onda se radi o specijalnom (ili, kako ga on u novijem izdanju naziva, izvanrednom apostolatu). Naposljetku, postoji i specijalizirani apostolat, koji na točno određenom području vrši ili pojedini vjernik laik ili skupina vjerni-

redovnice, ne pripadaju crkvenoj hijerarhiji i prema tome nisu pastiri Kristova stada. Njihova specifična zadaća jest težnja za savršenstvom i vlastito posvećenje, a ne apostolat. Prema tome, po svom pozivu nisu određeni za pastoralnu akciju u svijetu." Pastoralni radnik, 172.

38 Usp. Sergio Lanza, La teologia pastorale secondo la "scuola lateranense", u: Laterani 1 (2010.), 1, La teologia pastorale oggi, Lateran University Press, Rim, 2010., 13-65; usp. Ivan Pavao II., Christifideles laici - Vjernici laici. Apostolska pobudnica o pozivu i poslanju laika u Crkvi i u svijetu (30. XII. 1988.), KS, Zagreb, 1990., br. 26. (dalje: Christifideles laici).

39 Usp. Sergio Lanza, Il cristiano laico soggetto della edificazione e missione, u: Conferenza episcopale del Lazio - Commissione per il laicato, Cristiani laici missionari di cristo in un mondo che cambia, Atti del primo convegno regionale, Paoline, Roma, 2003., br. 22 (dalje: Il cristiano laico soggetto della edificazione e missione). 
ka. To točno određeno područje može biti primjerice posao socijalnog radnika, rad s mladima, rad sa studentima itd. ${ }^{40}$

\subsection{Područja apostolata: svij et i Crkva}

Premda Bezić područje apostolskog rada dijeli na crkveno i svjetovno, kao uostalom i drugi teolozi njegova vremena, ipak napominje kako se ta dva područja međusobno isprepleću te vjerniku nije nimalo jednostavno odijeliti vjerske i svjetovne elemente u svakodnevnom životu. Kako život postaje sve dinamičniji, složeniji, a društvo sve pluralnije, tako i sve zahtjevnijim postaje čovjeku vjerniku pomiriti u sebi građanske i vjerske dužnosti, vrednote i pravila. Uspije li ih integrirati i nauči li vještinu onoga 'dati caru carevo, a Bogu Božje' (usp. Mt 22, 21), onda je, ističe Bezić, prikladan za kršćanski apostolat. ${ }^{41}$ Ako, pak, ne uspije u toj zadaći da, recimo to tako, profanu dimenziju svog života prožme i oplemeni sakralnom dimenzijom, što će reći vlastitom duhovnošću, onda će patiti od dihotomije, rastrganosti i nutarnjeg nemira. Kako se to ne bi dogodilo, odgovornost je svakog kršćanina da na svim područjima života, kako privatnog tako i javnog, kako obiteljskog tako i profesionalnog, skladno integrira te dvije dimenzije na način da duhovna nikada ne bude podređena svjetovnoj, nego, štoviše, da je usmjeruje prema Bogu i ljudima.

Cjelokupni apostolat Bezić dijeli na dva velika područja: svijet i Crkvu. Područje apostolata u svijetu, nadalje, dijeli na nekoliko manjih potpodručja/sektora u kojima vjernik treba vršiti svoje kršćansko poslanje. Tako na prvome mjestu govori o obiteljskom apostolatu i dužnostima roditelja, zatim o staleškom apostolatu, tj. poslanju vjernika laika kroz različita zvanja, profesije ili staleže, gdje donosi zaista zanimljiva zapažanja o njihovim dužnostima. U područje staleškog apostolata tako svrstava seljake, varošane, građane, intelektualce, studente, namještenike, tehničare, radnike i privrednike, minuciozno navodeći njihove dužnosti i poželjni doprinos razvoju crkvenog poslanja. ${ }^{42}$

U apostolat u svijetu još svrstava i društveni apostolat, u kojem se posebno zalaže za društvenu jednakost i socijalnu pravdu, zatim apostolat javnog života, u kojem su posebno aktualne njegove misli o sve izraženijoj emigraciji, koja, kako ističe, demografski osiromašuje

$40 \quad$ Usp. Tko je apostol?, 49-66.

41 Isto, 94.

42 Isto, 95-118. 
Hrvatsku, stvara probleme i zemlji primateljici zbog poteškoća s integracijom te $u$ biti najviše odgovara poslodavcima zbog izobilja jeftine radne snage. Bezić ne ostaje samo na analizi i pogubnim posljedicama masovne emigracije nego nudi i mnoštvo konkretnih smjernica što učiniti, koje zbog kratkoće prostora nemamo mogućnosti potanje iznositi, a čitateljima mogu biti zanimljivi pa samo upućujemo na njih. ${ }^{43}$ Osim navedenih $\mathrm{u}$ apostolat $\mathrm{u}$ svijetu autor svrstava i zadaću kulturnog apostolata, u kojem najprije iznosi specifičnosti pojedinih područja, a zatim nudi obilje konkretnih smjernica kojima je svrha što plodonosnija integracija vjere i kulture u širem značenju, tj. vjere i znanosti, vjere i tehnologije, umjetnosti i masmedija itd.

Drugo veliko područje apostolata jest apostolat u Crkvi. Njega Bezić dijeli na župni apostolat, $u$ kojem na osobit način naglašava zadaću katehizacije djece, mladih i odraslih, ulogu vjeroučitelja te župnoga pastoralnog vijeća. Naglašava kako laici ne smiju biti samo statisti i gledatelji na misi, već moraju aktivno surađivati s glavnim liturgom kao ministranti, pjevači, čitači, sakristani i sl. ${ }^{44}$ Osim župnoga autor detaljno obrađuje biskupijski, katolički, ekumenski i misionarski apostolat. U svim navedenim sektorima nudi mnoge smjernice kako bi se apostolat što plodonosnije vršio. ${ }^{45}$

\section{KRITIČKI OSVRT NA BEZIĆEVO PROMIŠLJANJE APOSTOLATA}

3.1. Područja pastoralnog rada ne mogu se unaprijed odrediti

Kritički osvrt na Bezićevo promišljanje o apostolatu počet ćemo onim o čemu smo prethodno govorili - područjima pastoralnog rada. Područja pastoralnog rada osobito ad intra autor temelji na već uvriježen tradicionalan način, obilježen usmjerenošću na rad župnika u župnoj zajednici prema tridentskom modelu cura animarum i kristološkoj odrednici tria munera - Krista kao proroka, svećenika i kralja - izvlačeći iz njih područja pastoralnog djelovanja: katehezu (evangelizacija), liturgiju (sakramenti) i karitas (diakonija). ${ }^{46}$ To dakako nije u sebi teološki krivo, ali je nedovoljno sukladno suvremenoj teološko-pastoralnoj postavci pastoralnog rada jer izvodi (deduktivno) ili, bolje rečeno, reducira pastoralno djelovanje na već unaprijed oda-

43 Isto, 123, 124.

$44 \quad$ Usp. Pastoralni radnik, 226.

45 Usp. Tko je apostol?, 137-183.

46 Usp. Glavni vidovi pastoralne teologije i pastorala Živana Bezića, 45. 
brana područja ${ }^{47}$ Područja pastoralnog djelovanja, premda ih možemo unaprijed „predviđati“ uvijek pozorno čitajući „,znakove vremena“ očima vjere, ipak nastaju hic et nunc (ovdje i sada), u konkretnom ambijentu (mjestu, župnoj zajednici, pokretu i sl.). Drugim riječima, područja pastoralnog djelovanja nikada ne možemo unaprijed odrediti jer, osobito danas, u vrijeme brzih promjena, koje umnogome utječu i na crkveno područje i praksu vjere, nova područja (novi, moderni areopazi) neprestano nastaju, predstavljajući sve veći izazov crkvenom poslanju. Neke od takvih područja možemo samo spomenuti: ekologija, mediji (unutar kojih osobito mislimo npr. na evangelizaciju preko socijalnih mreža koje su danas iznimno popularne, osobito među mladima, a donedavno nisu uopće postojale), turizam, slobodno vrijeme itd.

\subsection{Pastoral nije samo dušobrižništvo}

Nakon pročitanih djela čitatelju postaje razvidno kako Bezić često poistovjećuje pastoral s dušobrižništvom. Tako u knjizi Suvremena župa tvrdi: „Čitavo to djelo spasavanja ljudi obično se naziva pastoral, jer ga Crkva vrši u duhu svoga pastirskog poslanja i u prvom redu preko crkvenih pastira. Sve njezino pastoralno djelovanje upravljeno je isključivo duhovnom dobru čovjeka. Župa je zato tu da se brine oko vjerskog dobra svojih članova te da im pomogne u ostvarivanju njihova spasa. To je ono što crkveni zakonik označuje sintagmom cura animarum“ ${ }^{48}$ To može ukazivati na činjenicu sužene percepcije onoga što osobito svećenik treba raditi, jer je Bezić pod pojmom pastoral podrazumijevao svećenički apostolat, o čemu smo prethodno govorili. U jednoj tako doista suženoj percepciji evangelizacijskog poslanja Crkve, koja na poseban način zapostavlja golemo područje socijalnog pastorala, možemo lako doći u opasnost te zaboraviti da nositelj pastoralnih aktivnosti u župnoj zajednici nije samo svećenik, već da je to cijela župna zajednica kao subjekt. ${ }^{49}$ Možemo se, nadalje, i kritički upitati: je li pastoralnoj teologiji stalo samo do duhovne izgradnje Crkve? Dovoljno je samo pročitati uvodne retke pastoralne konstitucije Drugoga vatikanskog

47 Usp. Sergio Lanza, La parrocchia in un mondo che cambia, Situazioni e prospettive, Edizioni OCD, Roma, 2004., 61-73.

48 Suvremena župa, 29.

49 Usp. Christifideles laici, br. 26; usp. Pastoralni radnik, 172; usp. Suvremena župa, 29. 
sabora Gaudium et spes da nam odgovor bude sasvim jasan. ${ }^{50}$ Treba ipak istaknuti i to kako Bezić, premda upotrebljava pojam dušobrižništvo i pastoral kao sinonime, nipošto ne upada u spiritualizirajuće kršćanstvo, nego se zauzima za čovjeka u cjelini. Štoviše, i više nego drugi pastoralni teolozi i teolozi općenito traži od svećenika i vjernika otvorenost i dijalog sa svima te brigu ne samo prema distanciranim vjernicima nego i prema ateistima. ${ }^{51}$

\subsection{Crkva je u službi ostvarenja kraljevstva Božjega}

Nadalje, možemo se pitati treba li Crkva kao zajednica vjernika biti jedini predmet i konačni cilj pastoralnog djelovanja? Drugim riječima, koje mjesto u crkvenom djelovanju zauzima kraljevstvo Božje? Zar ono ne bi trebalo biti stožerni obzor, temeljna perspektiva i krajnji cilj sveukupnog djelovanja Crkve? Odgovor je potvrdan. Koliko god je ekleziološko polazište, koje je uglavnom prisutno kod Bezića, a koje je on preuzeo od Antona Grafa i Karla Rahnera, čiji poznati pastoralni udžbenik rado navodi, proširilo perspektive i područje rada pastoralne teologije sa svećenika na sve članove Crkve, ipak je ono urodilo, gledano iz naše današnje perspektive, i stanovitom opasnošću tematskog sužavanja, tj. prevelikoj usredotočenosti na samu Crkvu, koja nas opet, htjeli - ne htjeli, vodi k ekleziocentrizmu. Samo se prisjetimo da je još pastoralni teolog Michael Sailer, prije gotovo 200 godina, zastupao mišljenje kako Crkva ne postoji radi same sebe, nego ona treba biti samo oruđe i sredstvo ostvarenja znatno višega, uzvišenijeg cilja - onoga što će Drugi vatikanski koncil u svojoj dogmatskoj konstituciji Lumen gentium reći o Crkvi: da je ona „sakrament, odnosno znak i sredstvo najprisnijega sjedinjenja s Bogom i jedinstva cijeloga ljudskog roda“. ${ }^{52}$ Drugim riječima, Crkva je u službi ostvarenja kraljevstva Božjega koje je u njoj vidljivo, ali je nadilazi. ${ }^{53}$

50 „Radost i nada, žalost i tjeskoba ljudi našeg vremena, osobito siromašnih i svih koji trpe jesu radost i nada, žalost i tjeskoba također Kristovih učenika, te nema ničega uistinu ljudskoga, a da ne bi našlo odjeka u njihovu srcu“. Gaudium et spes, br. 1.

$51 \quad$ Usp. Pastoralna teologija od Andrića do Bezića, 227.

52 Lumen gentium, 1.

53 Usp. Giovanni Villata, L'agire della Chiesa, indicazioni di teologia pastorale, Nuova edizione, EDB, Bologna, 2014., 151-152. (dalje: L'agire della Chiesa, indicazioni di teologia pastorale). 
3.4. Klerikalizam u pastoralu nije nešto što se tiče samo naše povijesti

Premda Bezić rado piše o klerikalizmu i kleričkom paternalizmu te upozorava na njegove negativnosti, ipak ne uviđa potrebu za većim i sustavnim doprinosom vjernika laika redovitom pastoralu. ${ }^{54}$ To se osobito odnosi na mogućnost ustanovljenja profesionalnih laičkih službi u Crkvi, što je na drugim područjima u Crkvi, osobito u Njemačkoj i Austriji, ali i u drugim državama, već odavno prisutno. ${ }^{55} \mathrm{O}$ klerikalizmu autor piše čak pomalo i nekritički, baveći se više semantikom samog pojma, njegovim osporavanjem u stvarnosti i zloporabom pojma, nego prepoznavanjem prevlasti kleričke dimenzije u crkvenom poslanju, u vremenu i prostoru u kojem trenutno živimo. ${ }^{56}$ Naime, Bezić puno više kritizira daleku povijest Crkve i njezine pogreške nego što svoje teološko pero kritički usmjeruje u odnosu na aktualnu crkvenu praksu i naslijeđe klerikalnog mentaliteta koji je, čini se, još duboko utkan u našu crkvenu svijest i sporo se mijenja. ${ }^{57}$

Uvažavajući društveno-političke okolnosti u kojima autor piše i težak, gotovo mučenički status Katoličke Crkve u poslijeratnom vremenu komunističke diktature, zacijelo se takav odnos i nedostatak samokritičnosti može razumjeti. Bilo mi možda i sasvim pretenciozno u takvim okolnostima u kojima je Crkva djelovala, osobito što se tiče izbacivanja njezine prisutnosti i utjecaja iz društvene dimenzije (vrtića, škola, fakulteta, bolnica, medija, itd.) i reduciranja na, kako to redovito kažemo, sakristiju, tražiti nedostatke kod sebe (iznutra). Rijetki bi tu samokritiku ispravno shvatili, dok bi većina u tome vidjela samo razbijanje zajedništva i narušavanje homogenosti koja je bila neophodna da se preživi to teško razdoblje. To se osobito odnosi na razdoblje neposredno poslije Drugoga svjetskog rata i do sredine šezdesetih godina prošlog stoljeća, točnije do Koncila i pokretanja Glasa Koncila, Veritasa, Kršćanske sadašnjosti itd., kada je represija sustava malo popustila i kad je Crkva pomalo počela izlaziti iz prisilne getoizacije. Navedeni argumenti, međutim, ne vrijede kad se radi o kasnijim radovima, primjerice o jednom radu

\footnotetext{
54 Usp. Pastoralni radnik, 161; usp. Suvremena župa, 146-150, 160-161.

55 Usp. Pastoralna služba, 26. Također se može reći kako se o istim službama na našem području već gotovo više od dva desetljeća intenzivno radi na znanstvenoteološkoj razini, ali istodobno i premalo na operativnoj razini, u smislu njihova znatnijeg zaživljavanja u praksi.

56 Usp. Živan Bezić, Što je klerikalizam, u: Crkva u svijetu 38 (2003.) 4, 564-581 (dalje: Što je klerikalizam?).

57 Isto, 571-577.
} 
o klerikalizmu iz 2003. godine, kad su se okolnosti stubokom promijenile, a nesnalaženje Crkve, u odnosu na nove potrebe vjernika i društva u cjelini, bilo više nego očito. ${ }^{58}$

\subsection{Cijela župna zajednica je subjekt pastorala}

Premda Bezić na više mjesta iznosi kako su i vjernici laici subjekti u pastoralu, ipak je, čini se, u promišljanju o poslanju vjernika laika u Crkvi i dalje zagovornik tradicionalne postavke pastorala, promišljanja koje prenaglašava značenje i ulogu zaređenih službenika Crkve nauštrb vjernika laika. U tom smislu u svojoj knjizi Tko je apostol? Bezić navodi kako su klerici glavni nositelji crkvenog pastorala, ${ }^{59}$ a laici i redovnici, u govoru o pomoćnom apostolatu o kojem smo i prethodno govorili, tek pomoćnici hijerarhije u hijerarhijskom apostolatu. ${ }^{60}$ Naravno, zaređeni službenici Crkve iznimno su važni, nezaobilazni, ali svakako treba istaknuti kako je cijela župna zajednica nositelj, subjekt pastorala. Također treba istaknuti kako redovnici i vjernici laici nisu subjekti tek u izvanrednom slučaju, npr. zbog nedostatka svećenika kojeg onda u vršenju nekih službi zamjenjuju, već su oni to u redovitom slučaju.

Drugim riječima, suodgovornost za poslanje Crkve svi krštenici primaju po krštenju. Ona se ne smije svesti samo na oblike pomoći/služenja koji su povjereni nekim laicima, pa bili to i oblici izvanredne suradnje, već se radi o specifičnom poslanju svakog vjernika na temelju krštenja. Ukratko, suodgovornost nije 'pomoć pastirima' (suradnja), nego ona predstavlja konstitutivni element života cijele župne zajednice, odnosno svakog krštenika. ${ }^{61}$ Svi su vjernici jednaki u zajednici, ali ne po kvaliteti i pozivu, nego po dostojanstvu i važnosti. Oni su također, prema darovima (karizmama) koje su primili, odgovorni za izgradnju kršćanske zajednice, da ona bude što više misionarska zajednica (organska i sinodalna).

Iz prethodno navedenog može se zaključiti (barem djelomično, i to zbog neujednačenosti autorovih promišljanja) kako Bezić laički angažman ipak nije smatrao posve samostalnim, nego ga je poimao kao aktivnu suradnju i participaciju vjernika laika u apostolatu crkvene hijerarhije. U kontekstu govora o važnosti zaređe-

58 Isto, 564-581.

59 Usp. Tko je apostol?, 30; Usp. Što je klerikalizam?, 567.

60 Usp. Tko je apostol?, 79-81.

61 Usp. Sergio Lanza, Convertire Giona, Pastorale come progetto, Edizioni OCD, Rim, 2008., 248; Paolo Asolan, Il pastore in una Chiesa sinodale, Una ricerca odegetica, Editrice San Liberale, Treviso, 2005., 432-437. 
nih i nezaređenih članova Crkve u pastoralnom djelovanju treba svakako istaknuti da se ni jedni ni drugi ne mogu shvatiti zasebno, niti mogu zasebno (autoreferencijalno) živjeti svoje poslanje: oni se mogu shvatiti samo u dinamičnom reciprocitetu. ${ }^{62}$ To hoće reći da se razumijevaju jedino jedni u odnosu na druge, tj. upućeni su jedni na druge - vjernici na svećenike i obrnuto. Tako jedni i drugi čine zajednicu koja je subjekt pastoralnog djelovanja.

Pristup poslanju vjernika laika koji nije uključivao njihovu izvornu odgovornost za poslanje Crkve u cjelini, nanio je velike štete Crkvi i ostavio velikog traga u njezinu djelovanju. Ponajviše to možemo primijetiti na mentalitetu koji još uvijek prevladava u našim župnim zajednicama i koji se jako sporo mijenja. Duga tradicija pasivizacije vjernika laika urodila je neželjenim plodovima: distanciranošću vjernika laika od Crkve (u nekim državama dovela je i do laicizma) i nerazvijenom sviješću o suodgovornosti za izgradnju kraljevstva Božjega. Sve je to slabilo svijest o pripadnosti Crkvi (sensus ecclesiae), a onda posljedično dovelo i do reducirane, ponegdje i samo formalne, pripadnosti Crkvi.

Kako je u proteklom razdoblju kod vjernika laika sve više porasla svijest o vlastitom ljudskom, vjerničkom i intelektualnom dostojanstvu i potrebi vrednovanja njihovih ljudskih i profesionalnih kompetencija, tako se sve teže nosimo s već spomenutim redukcijskim pristupom pastoralu i različitim oblicima naslijeđenoga baroknog paternalizma u Crkvi. Metanoia, promjena mentaliteta na svim razinama, koja bi urodila zaživljavanjem koncilske ekleziologije zajedništva te posljedično i većom uključenošću vjernika laika u poslanje Crkve, čini se još uvijek prioritetom u našem teološkopastoralnom kontekstu.

\subsection{Uloga pastoralnog vijeća}

Navedeno prenaglašavanje uloge svećenika, župnika, nauštrb ostalih članova župne zajednice vidi se, primjerice, i u govoru o ulozi pastoralnog vijeća u župi. Naime, kako nam je poznato, u tom participativnom, operativnom tijelu (pastoralnom vijeću) se, sukladno suvremenom poimanju teološko-pastoralnog rada u župi, analizira, diskutira, planira i stvara pastoralni plan za poslanje župne zajednice na svim područjima, u župi i izvan nje. ${ }^{63}$ Upravo se u tim ope-

62 Usp.Alojzije Čondić, Poslanjevjernikalaika upastoralunekadidanas, u: Crkvausvijetu 51 (2015) 2, 318; usp. Il cristiano laico soggetto della edificazione e missione, 89-90.

63 Pastoralna teologija ima zadaću teološki promišljati i programirati novu (poboljšanu) crkvenu praksu. Ona to čini sukladno vlastitoj pastoralnoj-teološkoj meto- 
rativnim tijelima i preko njih razvija duh sinodalnosti, potiče rast suodgovornosti i crkvenosti kod vjernika laika te posljedično dokida tradicionalna podjela na subjekte i objekte $u$ pastoralnom djelovanju. ${ }^{64} \mathrm{U}$ Bezićevu poimanju mjesta i uloge župnog pastoralnog vijeća u radu župe ono nije instrument koji putem evanđeoskog razlučivanja (metode pastoralne teologije) teološki analizira, planira i ostvaruje/provodi pastoralne projekte poboljšanja postojeće pastoralne prakse. Štoviše, u knjizi Tko je apostol? u govoru o timskom radu u poslanju mjesne Crkve nalazimo njegovu misao koja timski rad ne smatra nečim redovitim, poželjnim, već izvanrednim, nečim što se čini kad je osoba na rubu snaga pa ne može drugačije. U tom smislu on ističe da „ekipni rad (team-work) dolazi u obzir onda kad određeni zadatak nadilazi sile pojedinca“. ${ }^{65}$ Naravno da se može sasvim logično pretpostaviti kako se govor o tom pojedincu odnosi, prvenstveno ako već ne i isključivo, na svećenika, župnika. I na drugome mjestu u govoru o pastoralnom vijeću Bezić ističe nadiđenu viziju njegove uloge, koja u sebi umjesto teološkog promišljanja i projektiranja pastorala prikladnog konkretnom ambijentu u svakom smislu (jezičnom, kulturnom, komunikacijskom, socijalnom i sl.) ima gotovo samo obilježja adaptacije. ${ }^{66}$

\subsection{Važnost originalnosti i potreba strukturnih promjena}

Usprkos izrečenim kritikama, kod Bezića, jednog od naših najplodnijih pastoralnih teologa, možemo naći mnoge još uvijek relevantne i aktualne savjete glede što uspješnijeg pastoralnog djelovanja u Crkvi i društvu. U tom smislu rado ističemo njegovo naglašava-

dologiji, po metodi evanđeoske prosudbe. Usmjerena je uvijek na konkretnu situaciju, u kojoj, određujući pastoralni prioritet, projektira poboljšanje postojeće prakse stavljajući uvijek u recipročan odnos (asimetričan) nepromjenjive vrijednosti (zahtjeve) evanđelja i karakteristike (antropološke datosti) određene osobe, mjesta, zajednice, pokreta, vijeća itd. To čini na takav način slijedeći uvijek načelo utjelovljenja, koje utemeljuje, ali i kriteriološki određuje (kvalificira) cijeli metodološki proces projektiranje crkvene prakse.“ Usp. Sergio Lanza, La teologia pastorale secondo la "scuola lateranense", u: Laterani 1 (2010.), 1, La teologia pastorale oggi, Lateran University Press, Rim, 2010., 57; usp. Riccardo Tonelli, Incarnazione, u: Mario Midali \& Riccardo Tonelli, (ur.) Dizionario di pastorale giovanile, Elledici, Torino, 1992., 459.

64 Usp. L'agire della Chiesa, indicazioni di teologia pastorale, 159.

$65 \quad$ Tko je apostol?, 76.

66 „Župno pastoralno vijeće ima ulogu trafostanice za župu. Ono transformira i adaptira višu apostolsku djelatnost opće i biskupijske Crkve na lokalnu strujnu mogućnost mjesne Crkve. Ono se ujedno trudi da uklopi osnovnu kršćansku zajednicu u opća strujanja i nastojanja zavičajne i univerzalne crkve.“ Tko je apostol?, 83. 
nje osobnosti (originalnosti) kod svećenika i vjernika. Uviđajući promijenjene društvenih okolnosti, Bezić detektira promijenjeni odnos pojedinca i društva prema institucijama, strukturama općenito, a onda i crkvenim strukturama. Automatsko poštovanje i uvažavanje koje se prije snagom službe koju se vršilo podrazumijevalo i dobivalo, sada treba zaslužiti - razvijanjem osobnih kvaliteta. Drugim riječima, samo jake osobe, psihološki i duhovno jake i zrele te profesionalno kompetentne mogu druge ljude uspješno voditi. ${ }^{67}$ Osobito je to važno danas, u vremenu brzih promjena i mnoštva ljudi koji se zbog njih ne snalaze, već se osjećaju sasvim dezorijentirano ne znajući kome vjerovati, za što se žrtvovati, na kojim vrijednostima graditi život. Duhovno vodstvo i djelovanje osobito kroz male zajednice, pokrete, udruge, male krugove dobrote koji izgrađuju identitet od posebne je važnosti, ističe Bezić, jer one daju osjećaj sigurnosti i pripadnosti Božjem narodu koji je na hodočašću u kuću Božju. ${ }^{68}$

Nadalje, istaknuli bismo njegovu misao o nužnosti sustavnog, a ne sporadičnog karitativnog djelovanja. U tom smislu Bezić ističe: „Naš socijalni i karitativni rad ne smije biti vođen diletantski i amatersko-filantropski. On mora počivati na znanstvenoj bazi, usmjeren i potkrijepljen sociološkim studijama [...] i ne smije se ograničiti samo na materijalnu pomoć."69 Caritas je specifično kršćanska krepost i dužnost. To je temeljna funkcija Crkve. To je, ističe Bezić, sastavni i bitni dio, apsolutno nenadomjestiv dio kršćanskog života. Caritas je dužnost svakog kršćanina. Kao takva, ona se nikada ne smije prepustiti državi ili drugim javnim ustanovama pod izlikom da će one to bolje vršiti. ${ }^{70}$

Na poseban način unutar govora o konstitutivnosti Caritasa (dobrotvornosti) u poslanju Crkve autor, možemo to reći, dalekovidno ističe potrebu korjenitih, strukturnih promjena u društvu kako bi se određene anomalije (nepravde, korupcija, neslobode, zaostalost, siromaštvo) uklonile u cijelosti umjesto što se tek kozmetički saniraju preko pojedinih karitativnih akcija. Budući da su uzroci npr. siromaštva i zaostalosti u svijetu socijalne naravi, tj. društveno su uvjetovani, oni se ne mogu liječiti samo karitativnim radom, već strukturnim promjenama samih temelja društva. U tim mislima možemo vidjeti i poveznicu s današnjim mislima pape Franje, npr. u programatskoj apostolskoj pobudnici Evangelii gaudium, osobito

67 Usp. Pastoralni radnik, 176, usp. Pastoralni rad, 38, 64.

68 Usp. Pastoralna služba, 82-84.

69 Isto, 16-17.

70 Isto, 16. 
u drugom i četvrtom poglavlju ${ }^{71}$ kao i u pobudnici Amoris laetitae, gdje Papa osim prava pojedinca ističe i prava obitelji kao temeljne jedinice društva koja kao takva zavrjeđuje posebnu zaštitu i brigu na pravnom, gospodarskom, društvenom i poreznom području. ${ }^{72}$

\section{ZAKLJUČAK}

Koliko god se zamjerki našlo, a one se uglavnom, što se tiče naše teme, odnose na mnoge kontradiktornosti i iz današnje perspektive neadekvatan teološko-pastoralni diskurs o pastoralu i apostolatu, Bezićevo je djelo na području pastoralne teologije u Hrvatskoj od nemjerljive vrijednosti. Pritom posebno mislimo ma njegov teološko-pastoralni priručnik izdan u tri sveska, koji zapravo predstavlja jedinstvenu panoramu katoličke pastoralne teologije u Hrvatskoj. Premda Bezić u svojim teološko-pastoralnim promišljanjima rado citira Koncil, kao i druge teologe nositelje koncilskog duha, osobito s njemačkoga i francuskoga govornog područja, ipak nedovoljno ističe potrebu deklerikalizacije pastoralnog djelovanja i angažiranije uključivanje vjernika laika u pastoral, osobito onih koji su dobro poučeni u vjeri i kompetentni na profesionalnom području. Naravno, pri teološko-pastoralnom valoriziranju njegovih djela, osobito tu mislimo na pastoralnu trilogiju, treba uvijek imati na umu kako crkveni tako i društveno-politički kontekst druge polovice dvadesetog stoljeća $u$ kojem Bezić živi i djeluje, kao i činjenicu da se radi o priručnicima nastalim iz skripta iz kojih je autor predavao, $i$ to uglavnom (ako ne $i$ isključivo) kandidatima za svećeništvo. Imamo li u vidu sve navedeno, bit će nam lakše razumjeti Bezićev skolastički pristup, obilježen jasnom formulacijom, iznošenjem sadržaja s brojnim podjelama, specifičnom terminologijom, koja je katkad i previše juridičkog karaktera itd. S jedne strane možemo reći da je Bezić sam, kao uostalom i drugi ljudi, protagonist, ali $u$ isto vrijeme i 'dijete' svoga vremena, $\mathrm{s}$ druge strane. Ipak, u odnosu na druge, uzimajući pritom u obzir sve teme i područja kojima se bavio, autore koje je poznavao i u svojim radovima obilato citirao kao i cjelokupni opus koji je nakon svog plodnog teološko-pastoralnog rada ostavio, Živan Bezić sasvim sigurno spada u onaj uski krug ljudi koji su nastojali biti protagonisti, a ne samo 'konzumenti' duha vremena. U tom smislu utjecao je na formaciju mnogih generacija, bilo kao pastoralni teolog,

71 Usp. Papa Franjo, Evangelii gaudium - Radost evanđelja, Apostolska pobudnica o naviještanju evanđelju današnjem svijetu, KS, Zagreb, 2014., br. 50-109, 176-259.

72 Usp. Papa Franjo, Amoris laetitiae - Radost ljubavi, Posinodalna apostolaska pobudnica o ljubavi u obitelji, KS, Zagreb, 2016., br. 44. 
poučavajući, bilo kao dugogodišnji angažirani pastoralac, provodeći svoje zamisli u djelo. U kontekstu vremena u kojem je živio, osobito misleći pritom na različita previranja na području pastoralne teologije kao i na društveno-političke (ne)prilike i nesklonost nedemokratskoga totalitarističkog sustava Crkvi i njezinu poslanju, osobito u njezinu djelovanju ad extra, navedene kritike koje smo u tekstu iznijeli gube svoju oštricu. Svojim neumornim, svestranim i sustavnim radom kao i neprijepornom erudicijom Bezić je dao nemjerljiv doprinos razvoju i znanstvenoj relevantnosti postkoncilske pastoralne teologije u Hrvatskoj.

\section{CRITICAL REVIEW OF THE CONCEPT OF APOSTOLATE IN THE WORKS OF ŽIVAN BEZIĆ}

\section{Summary}

In the paper the author reflects on the apostolate on the basis of the written books and articles of Živan Bezić, one of the most prolific pastoral theologians in Croatia in the second half of the last century. In the first part he presents Bezić's theological-pastoral thoughts on the meaning, historical use and foundation of the apostolate. In the second part he speaks of the division, purpose and areas of apostolate. In the third part, in the light of contemporary achievements of pastoral theology and from the point of view of the Lateran School, the author critically refers to Bezić's theologicalpastoral reflections on the apostolate, on its division and areas and subjects of the apostolate. Bezić, the pastoral theologian, perceives the apostolate in a traditional spirit and does not use the term itself monosemically in his works.

Key words: Živan Bezić, apostolate, pastoral work, pastorization, lay faithful 